In this Issue:

ACRL Candidates, 1979 Elections

ACRL Members Run for ALA Council

Continuing Education-XI

LAUC Resolution

ARL Salary Survey

News from the Field

People

.39

Publications

Classified Advertising \\ COLLEGE RESEARCH LIBRARIES MQJWS
}

NO. 2 • FEBRUARY 1979

\section{ACRL Candidates, 1979 Elections}

\section{Vice-President/President-Elect}

Millicent D. Abell, Director, University Libraries, The University of California-San Diego, La Jolla, CA 90293; Susan Brynteson, Assistant Director for Technical Services, University Libraries, Indiana University, Bloomington, IN 47401 .

\section{Agriculture aNd Biological SCIENCES SECTION}

Vice-Chair/Chair-Elect: Tom Kirk, Science Librarian, Earlham College, Richmond, IN 47374; Dorothy B. Skau, Librarian, U. S. Department of Agriculture, Southern Regional Research Center, Box 19687, New Orleans, LA 70179.

Secretary (one-year term): Anaclare F. Evans, Shiffman Medical Library, Wayne State University, Detroit, MI 48201; Arne Richards, Documents Librarian, Kansas State University, Manhattan, KS 66506.

\section{ANTHROPOLOGY SECTION}

Vice-Chair/Chair-Elect: Suzy Slavin, 4054 Northcliffe Ave., Montreal, Quebec, Canada, H3A 4LA; Patricia White, Michigan State University Library, East Lansing, MI 48824.

Secretary (two-year term): Lynne $M$ Schmelz-Keil, Rutgers University, Dana Library, Newark, NJ 07102; Karen Wittenborg, SUNY/ Albany, 1400 Washington Ave., Albany, NY 12222

Member-at-Large (two-year term): Elizabeth Corbett, Barnard College, Wollman Library, New York, NY 10027; Kenneth Parker, Box 3781, Stanford, CA 94305.

\section{ART SECTION}

Vice-Chair/Chair-Elect: Jaylyn Olivo, 98 Longwood Ave., Apt. 2, Brookline, MA 02146;
Jane Anne Snider, Herron School of Art, Library, 16 th and N. Pennsylvania Ave., Indianapolis, IN 46202.

Secretary (two-year term): Philip Heagy, Reference Assistant, Fine Arts Library, Indiana University, Bloomington, IN 47401.

\section{AsIaN aNd AfRican SECTION}

Vice-Chair/Chair-Elect: Naimuddin Qureshi, Assistant Professor, Division of Library Science, California State University, Fullerton, CA 92634; E. Christian Filstrup, First Assistant, Oriental Division, The Research Libraries, New York Public Library, New York, NY 10018.

Secretary (three-year term): Janet A. Krompart, Associate Dean, Oakland University Library, Rochester, MI 48063; Frances Morton, Middle East Bibliographer, Indiana University Libraries, Bloomington, IN 47401.

Member-at-Large (three-year term): Gail J. Grise, Africana Cataloger, Indiana University $\mathbf{L i}$ braries, Bloomington, IN 47401; Ravindra N. Sharma, Senior Reference Librarian, Colgate University Library, Hamilton, NY 13346.

\section{Bibliographic Instruction SECTION}

Vice-Chair/Chair-Elect: Sharon Rogers, Social Science Specialist, University of Toledo, Toledo, OH 43606; James E. Ward, Director of the Library, David Lipscomb College, Nashville, TN 37203.

Secretary-Treasurer: Janice T. Koyoma, Coordinator of Reference and Instructional Services, California State University, Long Beach, CA 90840; Joan Stockard, Readers Services Librarian, Wellesly College, Wellesly, MA 02181.

Member-at-large: Cerise Oberman-Soroka, Head of Reference, College of Charleston, Char- 
leston, SC 29401; Beverly Renford, Assistant Librarian, Pennsylvania State University, University Park, PA 16802.

\section{College Libraries Section}

Vice-Chair/Chair-Elect: Bob Carmack, I. D Weeks Library, University of South Dakota, Vermillion, SD 57069; Willis M. Hubbard, Director, Hugh Stephens Library, Stephens College, Columbia, MO 65201.

Secretary (one-year term): Sister Patricia Hodge, RSM, Director, Library, Trinity College, Burlington, VT 05401; William Newman, Acting Director of Libraries, York University, 4700 Keele Street, Downsview, Ontario, Canada M3J 2R2.

\section{Community and Junior College LIBRARJES SECTION}

Vice-Chair/Chair-Elect: Barbara Collinsworth, Associate Dean of Learning Resources, Macomb County Community College, Center Campus, P. O. Box 309, Warren, MI 48093; Sidney August, Director, Educational Resources Center, Community College of Philadelphia, $34 \mathrm{~S}$. Eleventh St., Philadelphia, PA 19107.

Secretary: Ruth Person, Coordinator of Continuing Education, School of Library Science, University of Michigan, Ann Arbor, MI 48109; Pamela Reierson, Media Specialist, Learning Resources Center, Normandale Community College, $9700 \mathrm{France}$ Avenue South, Bloomington, MN 55431.

\section{EDUCATION AND BEHAVIORAL SCIENCES SECTION}

Vice-Chair/Chair-Elect: Eva L. Kiewitt, Associate Librarian, Graduate Library School, University Library School, University Library, Indiana University, Bloomington, IN 47401; Marianna Markowetz, Assistant Director of Public Services, University of Wisconsin-Milwaukee Library, Milwaukee, WI 53201.

Secretary: Ruth Murray, Education/Behavioral Science Bibliographer, Regenstein Library, University of Chicago, Chicago, IL 60637; L. James Olivetti, Education/Psychology Reference Librarian, George Mason University Drive, Fairfax, VA 22030.

\section{Law and Political Science Section}

Vice-Chair/Chair-Elect: James B. Alsip, Associate Director of Technical Services, The University of Oklahoma, $401 \mathrm{~W}$. Brooks, Room 141, Norman, OK 73019; Frances H. Hall, Librarian, North Carolina Supreme Court Library, P. O. Box 28006, Raleigh, NC 27611.

Secretary (three-year term): Thelma Freides, Head of Reader Services, State University of New York College at Purchase, Purchase, NY
10577; Willis M. Hubbard, Director, Hugh Stephens Library, Stephens College, Columbia, MO 65201 .

Member-at-Large: Donald J. Dunn, Law Librarian, Western New England College, Springfield, MA 01119; Robert Goehlert, Librarian for Economics and Political Science, The University Libraries, Indiana University, Bloomington, IN 47401.

\section{Rare Books and Manuscripts Section}

Vice-Chair/Chair-Elect: Helen S. Butz, Head, Rare Books Cataloging Division, University Library, University of Michigan, Ann Arbor, MI 48109; Kenneth E. Carpenter, Curator, Kress Library of Business and Economics, Baker Library, Graduate School of Business Administration, Harvard University, Soldiers Field, Boston, MA 02163.

Secretary (two-year term): Stephen Ferguson, Princeton University Library, Princeton, NJ 08540; Marilyn Wurzburger, Head, Special Collections, University Library, Arizona State University, Tempe, AZ 85281.

Member-at-Large (three-year term): John Lancaster, Special Collections Librarian and Archivist, Amherst College, Amherst, MA 01002; L. C. Rudolph, Lilly Library, Indiana University, Bloomington, IN 47401.

\section{Slavic and East European Section}

Vice-Chair/Chair-Elect: E. Alex Baer, Head, Ref./Collection Development Department, University Libraries, Virginia Polytechnic Institute and State University, Blacksburg, VA 24061; Wojciech Zalewski, Russian and East European Materials, Main Library, Stanford University, Stanford, CA 94305.

\footnotetext{
News items for inclusion in C\&RL News should be sent to Jeffrey Schwedes, ACRL, American Library Associatıon, $50 \mathrm{E}$ Huron St., Chicago, IL 60611 . Display advertısing should be sent to Leona Swiech, Advertising Office, ALA. Send classified ads to ACRL. Production and circulation matters are handled by ALA Central Production Unit at the above address.

News editor: John V. Crowley, Assistant Director of Libraries, Milne Library, State University College, Oneonta, NY 13820, telephone (607) 431-2725. Assistant news editor: Ellen L. Huyler, Assistant Librarian, Acquisitions Department, Milne Library, State University College, Oneonta, NY 13820. Editor: Richard D. Johnson, Milne Library, State University College, Oneonta, NY 13820. President, ACRL Evan I. Farber. Executive Secretary, ACRL Julie A. Carroll Virgo.

College \& Research Libraries is published by the Association of College and Research Libraries, a division of the American LI. brary Association, 17 times yearly -6 bimonthly joumal issues and 11 monthly (combining July-August) News issues-at 50 E. Huron St. Chicago, IL 60611. Subscription, $\$ 25.00$ a year, of to members of the division, $\$ 12.50$, included in dues. Second-class postage paid at Chicago, Iltinois, and at additional mailing offices.
}

(C) American Library Association 1979. All material in this journal subject to copyright by the American Librany Association may be photocopied for the noncommercial purpose of scientific or educational advancement. 
Member-at-Large (one-year term): Marie Bednar, Assistant to the Head, Slavic Library Program, University Libraries, Pennsylvania State University, University Park, PA 16802; Laszlo L. Kovacs, Librarian, School of Humanities, Social Science and Education, Purdue University Libraries, West Lafayette, IN 47907.

\section{UNIVERSITY LibRaRIES SEction}

Vice-Chair/Chair-Elect: Joanne Harrar, Direc- tor, Library Science, University of Maryland, McKeldin Library, College Park, MD 20742; Richard J. Talbot, University of Massachusetts, Amherst, MA 01002.

Secretary (three-year term): Naimuddin Qureshi, Assistant Professor, California State University, 800 N. State College Blvd., Box 4150, Fullerton, CA 92634; Judy Harvey Sahak, Assistant Director of Libraries, The Claremont Colleges, Ninth \& Dartmouth Sts., Claremont, CA 91711. .

\section{ACRL Members Run for ALA Council}

The following members of the Association of College and Research Libraries have been nominated as candidates for ALA councilor in the spring 1979 elections. Members are encouraged to vote for these candidates to increase ACRL's voice in the affairs of the American Library Association.

Elaine P. Adams, Coordinator, Learning Resources Center, Texas Southern University Library, Houston

Ronald Blazek, Associate Professor, School of Library Science, Florida State University, Tallahassee

William S. Budington, Executive Director and Librarian, John Crerar Library, Chicago, Illinois

Sheila Dowd, Assistant University Librarian for Collection Development and Reference Services, University of California, Berkeley

Allan J. Dyson, Head, Moffitt Undergraduate Library, University of California, Berkeley

Ambrose Easterly, Director of Library Services, William Rainey Harper College, Palatine, Illinois

Shirley A. Edsall, Director, Learning Resources Center, Wilson Memorial Hospital, Johnson City, New York

Bernard M. Fry, Dean, Graduate Library School, Indiana University, Bloomington

Dean W. Halliwell, University Librarian, University of Victoria, Victoria, British Columbia, Canada

Beth Hamilton, Director, Illinois Regional Library Council, Chicago, Illinois

William C. Highfill, University Librarian, Auburn University Libraries, Auburn, Alabama

Daniel W. Lester, Assistant Dean for Technical Services, University of New Mexico General Library, Albuquerque

Beverly P. Lynch, University Librarian, University of Illinois at Chicago Circle

Sister Lauretta McCuster, Dean, Rosary College, Graduate School of Library Science, River Forest, Illinois
Richard E. Miller, Director, Oshkosh Public Library, Oshkosh, Wisconsin

Ronald Naylor, Personnel Officer, University of Maryland Libraries, College Park

Richard Olsen, Director, James P. Adams Library, Rhode Island College, Providence

Lelia G. Rhodes, Director, Jackson State University Library, Jackson, Mississippi

C. James Schmidt, Director of Libraries, State University of New York, Albany

Thomas W. Shaughnessy, Assistant Director for Public Service and Collection Development, University of Houston, Houston, Texas

Kenneth E. Toombs, Director of Libraries, Thomas Cooper Library, University of South Carolina, Columbia

Herman Totten, Associate Dean, School of Library and Information Science, North Texas State University, Denton

Avery Williams, Reference Librarian, Roosevelt University Library, Chicago, Illinois.

\section{Librarian Is AAUP President}

The new president of the American Association of University Professors (AAUP) is Martha Friedman, associate professor and history and philosophy librarian at the University of Illinois, Urbana. She has been a member of the university faculty since 1965 with her particular area of research being the history of American academic libraries and the development of ideas of professionalism in librarianship. Friedman has served on the Faculty Senate at the University of Illinois and has been the chairperson of the Senate Council since 1976. She has also been a member of numerous other campus committees. Since 1965, when she joined AAUP, she has held many chapter and conference offices and recently completed a term as first vice-president of AAUP. 